\title{
Pengaruh Service Quality Terhadap Customer Loyalty Melaui Customer Satisfaction Pelanggan Jawa Pos Radar Jember
}

\author{
Narto $^{1}$, Suwignyo Widagdo ${ }^{2}$, Agustin Hari Prastyowati ${ }^{3}$ \\ Sekolah Tinggi Ilmu Ekonomi Mandala, Jember
}

\begin{abstract}
For print media, maintaining and adding customers is very important in today's digital era. Including Jawa Pos Radar Jember. Companies must improve Service Quality (service quality), to create and maintain Customer Loyalty (loyal customers). This research is quantitative descriptive. This study was conducted on Jawa Pos Radar Jember customers in Jember Regency, precisely in Sumbersari, Patrang and Kaliwates Regencies. Data collection techniques by observation, questionnaire and direct interview. The number of samples was 125 out of a population of around 7,500 subscribers to the Jawa Pos Radar Jember newspaper. This study uses Service Quality independent variables (Tangibility, Reliability, Responsiveness, Assurance, Empathy), Customer Satisfaction variables and Customer Loyalty dependent variables. The analytical method used is multiple regression analysis with path analysis, classic assumption test (multicollinearity test, heteroscedasticity test, and normality test). The purpose of this study is 1) to test and analyze Reliability, Responsiveness, Assurance, Empathy effect on Customer Satisfaction and Customer Loyalty. 2) Test and analyze the moderation of Customer Satisfaction against Customer Loyalty. The results show that Tangibility, Responsiveness, Assurance, Empathy has no significant effect on Customer Satisfaction. Only reliability has a significant effect on Customer Satisfaction. Conversely, Reliabilty, Responsiveness, Assurance, Empathy has a significant effect on Customer Loyalty. Only, Tangibility is not a significant effect on Customer Loyalty. And Customer Saticfaction does not become intervening between Service Quality and Customer Loyalty.
\end{abstract}

Keywords: Service Quality, Customer Satisfaction dan Customer Loyalty.

\section{Pendahuluan}

Revolusi Industri 4.0 sekarang ini benar-benar berpengaruh nyata terhadap keberlangsungan media massa, khususnya media cetak. Menjamurnya media daring di era digital menjadi menjadi ancaman besar bagi media cetak. Media cetak saat ini berupaya keras untuk bertahan dari ancaman media daring yang makin kuat mengambil alih peran media cetak dalam menyebarkan informasi. Media daring punya keunggulan yang tidak dimiliki media cetak. Berita yang dipublikan lebih 
cepat dari pada media cetak yang harus menunggu satu hari berikutnya.

Semua media cetak kini berjuang keras untuk memelihara sekaligus mempertahankan para pelanggannya. Sekjen Aliansi Jurnalistik Indonesia (AJI) Suwardjono (2013) ketika menjadi panelis Seminar New Media: Pembaca, Laba dan Etika, yang diselenggarakan, di Palembang mengatakan, kehadiran teknologi informasi sehingga melahirkan media online ini sungguh luar biasa dampaknya terhadap percepatan komunikasi di negeri ini. "Terbukti, kini media massa cetak nasional menghadapi stagnansi akibat pembaca sudah beralih ke portal berita," ujarnya.

Mempertahankan pelanggan sama halnya mempertahankan kelangsungan hidup perusahaan media cetak. Sebab, konsumen media cetak sebagian besar merupakan pelanggan. Pelanggan media cetak yang lama masuk fase konatif: Itu ditunjukkan komitmen pelanggan yang tinggi dengan ditujukkan dengan keinginan untuk melakukan pembelian lagi dan melakukan rekomendasi merek kepada orang lain (Widiyono, Hakim, 2018).

Nielsen Indonesia mencatat, jumlah media cetak mengalami penurunan, khususnya majalah dari 162 judul pada tahun 2012 menjadi 96 judul pada tahun 2017. Sedangkan surat kabar turun tiga judul dalam periode yang sama, yaitu dari 102 menjadi 99 judul. (http://marketeers.com, 2017).

Dua hal yang menjadi pertimbangan utama perusahaan dalam mempertahankan loyalitas pelanggan adalah, pertama karena semakin mahalnya biaya perolehan pelanggan baru dalam iklim kompetisi yang ketat. Kedua adalah kenyataan tingkat kemampuan perusahaan berbanding lurus dengan pertumbuhan hubungan antara perusahaan dan pelanggan secara permanen. Seorang pelanggan yang loyal akan menjadi aset yang berharga bagi suatu perusahaan. "Apabila perusahaan ingin menciptakan pelanggan yang loyal terhadap produk maka perusahaan harus meningkatkan kualitas layanan yang diberikan kepada pelanggannya". (Tjiptono, 2009).

Perusahaan media cetak menggunakan berbagai strategi untuk merebut dan mempertahankan konsumen. Salah satunya meningkatkan kualitas pelayanan terhadap pelanggannya. Kotler dan Keller (2017) juga mengatakan bahwa perilaku 
tersebut dapat terjadi pada saat, sebelum dan sesudah terjadinya transaksi. Kualitas layanan adalah segala bentuk aktivitas yang dilakukan oleh perusahaan guna memenuhi harapan konsumen

Perusahaan media cetak harus meningkatkan keahlian demi membantu masyarakat yang membutuhkan layanan informasi yang diinginkan. Perusahaan harus menangkap peluang pasar khusus (niche market), dan melakukan berbagai kegiatan spesial demi menjalin hubungan baik dengan pembaca mereka. (newspaper.pikiranrakyat.com).

Berdasarkan teori dan penelitian terdahulu terhadap media cetak yang kebanyakan menyatakan bahwa Service Quality dan Customer Satisfaction berpengaruh signifikan Customer Loyalty maka penulis meneliti Pengaruh Kualitas Layanan (Service Quality) Terhadap Loyalitas Pelanggan (Customer Loyalty) melalui Customer Satisfaction. Studi Kasus pada Pelanggan Jawa Pos Radar Jember).

\section{Hipotesis}

Kualitas layanan (Service Quality) dapat memberikan dampak kepada loyalitas konsumen (Customer Loyalty) (Kotler dan Keller, 2017) melalui Customer Satisfaction. Berdasarkan latar belakang masalah di atas maka diperoleh rumusan masalah sebagai berikut:

1. Apakah Tangibility berpengaruh terhadap Customer Satisfaction

2. Apakah Reliability berpengaruh terhadap Customer Satisfaction

3. Apakah Responsiveness berpengaruh terhadap Customer Satisfaction

4. Apakah Assurance berpengaruh terhadap Customer Satisfaction

5. Apakah Empathy berpengaruh terhadap Customer Satisfaction

6. Apakah Tangibility berpengaruh terhadap Customer Loyalty

7. Apakah Reliability berpengaruh terhadap Customer Loyalty

8. Apakah Responsiveness berpengaruh terhadap Customer Loyalty

9. Apakah Assurance berpengaruh terhadap Customer Loyalty

10. Apakah Empathy berpengaruh terhadap Customer Loyalty

Apakah Customer Satisfaction memediasi antara Service Quality 


\section{Metode Penelitian}

Penelitian dilakukan di Kabupaten Jember sebagai daerah yang menjadi wilayah edar Jawa Pos Radar Jember yang beralamat di Jl Ahmad Yani 99 Jember. Telepon (0331) 486894, email: radarjember@gmail.com. Penelitian dilakukan mulai Oktober sampai Desember 2018.

Populasi penelitian ini adalah sejumlah pelangggan koran Jawa Pos Radar Jember. Khususnya yang tinggal di Kecamatan Sumbersari, Kaliwates dan Patrang Kabupaten Jember. Pelanggan koran Jawa Pos Radar Jember terbanyak di Sumbersari, Kaliwates dan Patrang. Berdasarkan Company Profile Jawa Pos Radar Jember (2015), pelanggan total di Kabupaten Jember, Lumajang dan Bondowoso 15.000. Dengan perbandingan 50 persen Jember, 25 persen Lumajang dan 25 persen Bondowoso. Maka populasi pelanggan koran Jawa Pos Radar Jember dalam penelitian ini sekitar 7.500 .

Menurut Ferdinand (2014) dalam beberapa penelitian multivariate (termasuk yang menggunakan analisis regresi multivariate besarnya sampel ditentukan sebanyak 25 x variabel independen. Sampel yang digunakan oleh peneliti 25 x 5 variabel independen yaitu menggunakan 125 orang responden pelanggan koran Jawa Pos Radar Jember dari sekitar 7.500 pelanggan koran Jawa Pos Radar Jember.

Metode menentukan sampel dalam penelitian ini adalah dengan menggunakan sampling purposive (Sugiyono, 2017). Dengan menentukan secara sengaja sampel penelitian yang dipilih suatu pertimbangan tertentu. Dalam hal ini adalah sampel yang diambil peneliti adalah pelanggan Jawa Pos Randar Jember yang berlangganan mingguan, bulanan atau tahunan. Yaitu pelanggan yang membayar tiap minggu, bulan atau setahun sekali. Bukan pelanggan yang beli eceran. Sebaran pelanggan khusus di Kecamatan Sumbersari, Patrang dan Kaliwates Kabuaten Jember. Peneliti menyebarkan kusioner kepada 125 responden yang menjadi sampel pelanggan Jawa Pos Radar Jember.

'Metode pengumpulan data yang dilakukan peneliti dalam penelitian ini dilakukan dengan metode kuisioner, wawancara atau tidak langsung, observasi dan studi pustaka. Rensis Likert telah mengembangkan sebuah skala untuk mengukur sikap 
masyarakat di tahun 1932 yang sekarang terkenal dengan nama Skala Likert. Menurut Ghozali (2016), Skala Likert adalah suatu skala psikometrik yang digunakan dalam kuesioner. Skala Linkert merupakan salah satu teknik yang dapat digunakan dalam evaluasi suatu program atau kebijakan perencanaan.

\section{A. Metode Analisis Data}

Metode analisis data yang digunakan dalam penelitian ini adalah regresi linier berganda yaitu dengan:

\section{Uji Validitas}

Yang dimaksud Uji Validitas adalah untuk menguji apakah ada kesesuaian antara bagian-bagian instrumen dengan instrumen secara keseluruhan. Dengan demikian uji validitas internal yang dilakukan dengan cara mengorelasikan antara masing-masing butir-butir pertanyaan terhadap skor totalnya yang ada.

Data yang diperlukan dalam rumus adalah:

$$
\begin{gathered}
r_{x y}=\frac{N \sum X Y-\left(\sum X\right)\left(\sum Y\right)}{\sqrt{\left(N \sum X^{2}-\left(\sum X\right)^{2}\left\{N \sum Y^{2}-\left(\sum Y\right)^{2}\right)\right.}} \\
\sum \mathrm{X}=\ldots \sum \mathrm{Y}=\ldots \sum \mathrm{XY}=\ldots \sum \mathrm{X} 2=\ldots \sum \mathrm{Y} 2=\ldots \mathrm{n}=\ldots
\end{gathered}
$$

$\mathrm{X}=$ Skor yang diperoleh subyek dari seluruh item

$\mathrm{Y}=$ Skor total yang diperoleh dari seluruh item

$\Sigma \mathrm{X}=$ Jumlah skor dalam distribusi $\mathrm{X}$

$\Sigma \mathrm{Y}=$ Jumlah skor dalam distribusi $\mathrm{Y}$

$\Sigma \mathrm{X} 2=$ Jumlah kuadrat dalam skor distribusi X

$\Sigma Y 2=$ Jumlah kuadrat dalam skor distribusi Y

$\mathrm{N}=$ Banyaknya responden

\section{Uji Reliabilitas}

Uji reliabilitas merupakan suatu instrumen cukup dapat dipercaya sebagai alat pengumpulan data karena instrumen tersebut sudah baik. Reliabilitas yang digunakan adalah reliabilitas internal yaitu reliabilitas yang diperoleh dengan cara menganalisis data dari satu kali hasil pengetesan. Uji Reliabilitas dilakukan dengan uji Alpha Cronbach. Rumus Alpha Cronbach sebagai berikut: 
$\alpha=\left(\frac{K}{K-1}\right)\left(\frac{s_{r}^{2}-\sum s_{i}^{2}}{s_{X}^{2}}\right)$

catatan:

$\alpha=$ Koefisien reliabilitas Alpha Cronbach

$\mathrm{K}=$ Jumlah item pertanyaan yang diuji

$\sum s_{i}^{2}=$ jumlah varians skor item

$s_{x}^{2}=$ varian skor-skor tes (seluruh item K)

Jika nilai alpha $>0,7$ artinya reliabilitas mencukupi (sufficient reliability) sementara jika alpha >0,80 ini mensugestikan seluruh item reliabel dan seluruh tes secara konsisten secara internal karena memiliki reliabilitas yang kuat.[3] Atau, ada pula yang memaknakannya sebagai berikut:

Jika alpha > 0,90 maka reliabilitas sempurna

Jika alpha antara 0,70 - 0,90 maka reliabilitas tinggi

Jika alpha antara 0,50 - 0,70 maka reliabilitas moderat

Jika alpha $<0,50$ maka reliabilitas rendah

Jika alpha rendah, kemungkinan satu atau beberapa item tidak reliabel: Segera identifikasi dengan prosedur analisis per item. Item Analysis adalah kelanjutan dari tes Aplha sebelumnya guna melihat item-item tertentu yang tidak reliabel. Lewat ItemAnalysis ini maka satu atau beberapa item yang tidak reliabel dapat dibuang sehingga Alpha dapat lebih tinggi lagi nilainya.

\section{B. Uji Asumsi Klasik}

Uji asumsi klasik digunakan lebih dahulu untuk menguji hipotesis. Dimana Uji uji asumsi klasik dilakukan dengan menggunakan alat uji statistik, yaitu:

\section{1) Uji Normalitas}

Uji normalitas digunakan untuk menguji apakah model dalam regresi, variabel terikat dan variabel bebas keduanya mempunyai distribusi normal atau tidak. Ghozali, (2016): Sedangkan Menurut Priyatno (2012), dasar pengambilan keputusan yaitu sebagai berikut:

(1) Nilai Probabilitas > 0,05, maka hal ini berarti bahwa data tersebut berdistribusi normal.

(2) Nilai Probabilitas $<0,05$, maka hal ini berarti bahwa data tersebut tidak 
berdistribusi normal.

\section{2) Uji Multikolinieritas}

Uji Multikolinieritas untuk mengetahui tidak ada multikolinearitas diantara variabel bebas, artinya tidak terjadi hubungan antara variabel bebas. Menurut Priyatno (2012), deteksi tidak adanya Multikolinieritas yaitu:

(1) Mempunyai nilai VIF lebih kecil dari 10

(2) Mempunyai angka tolerance mendekati 1

\section{3) Uji Heteroskedastisitas}

Uji heteroskedatisitas bertujuan menguji apakah model regresi terjadi ketidaksamaan varian dari residual satu pengamatan-pengamatan yang lain. Pendeteksian adanya heteroskedaktisitas menurut Priyatno (2012), jika sebaran titik-titik berada di atas dan di bawah angka nol pada sumbu $\mathrm{Y}$ dan tidak membentuk pola yang jelas, maka tidak terjadi heteroskedaktisitas.

\section{Analisis Jalur/Path Analysis}

Analisis jalur ini bertujuan untuk mengetahui pengaruh langsung dan tidak langsung, secara simultan atau parsial beberapa variabel eksogenus terhadap sebuah variabel endogenus. Dalam penghitungan digunakan jasa komputer breupa software dengan program SPSS For Windows Versi 22 (Riduwan, 2017).

Langkah-Langkah menguji analisis jalur (Riduwan, 2017) sebagai berikut:

1. Merumuskan hipotesis dan persamaan struktural

$$
\text { Struktur: } \mathrm{Y}=\mathrm{P}_{\mathrm{yx} 1} \mathrm{X} 1+\mathrm{P}_{\mathrm{yx} 1} \mathrm{X} 2+\mathrm{P}_{\mathrm{y}} \Sigma_{1}
$$

2. Menghitung koefisien jalur yang didasarkan pada koefisien regresi

a. Gambarkan diagram jalur lengkap, tentukan substruktur dan rumuskan persamaan strukturalnya yang sesuai dengan hipotesis yang diajukan

b. Menghituang koefisien regresi untuk struktur yang telah dirumuskan.

Hitung koefisien regresi untuk struktur yang telah dirumuskan ;

Persamaan regresi ganda: $\mathrm{Y}=\mathrm{a}+\mathrm{b} 1 \mathrm{x} 1+\mathrm{b} 1 \times 2+\Sigma_{1}$

Khusus untuk program SPSS menu analisis regresi, koefisien path ditujukkan oleh out put yang dinamakan Coefficient yang dinyatakan 
sebagai Standardzed Coefificient atau dikenal dengan nilai Beta. Jika ada diagram jalur sederhana mengandung satu unsur hubungan antara variabel eksogen dengan variabel endogen, maka koefisien path-nya adalah sama dengan koefisien korelasi r sederhana.

3. Menghitung koefisien jalur secara simultan (keseluruhan)

Uji secara keseluruhan hipotesis statistik dirumuskan sebagai berikut :

Ha $: \operatorname{pyx} 1=\operatorname{pyx} 2=\ldots \ldots . .=\operatorname{pyxk} \neq 0$

Ho $: \operatorname{pyx} 1=\operatorname{pyx} 2=\ldots \ldots . .=\operatorname{pyxk}=0$

a. Kaidah pengujian signifikansi secara manual menggunakan Tabel $\mathrm{F}$

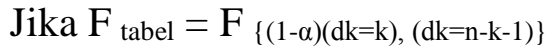

b. Kaidah signifikansi program SPSS

- Jika probabilitas 0,05 lebih kecil atau sama dengan nilai probabilitas Siq atau $(0,05 \geq$ Siq) maka Ho ditolak dan ha diterima

1. Menghitung koefisien jalur secara individu/ parsial

Hipotesis penelitian yang akan diuji dirumuskan menjadi hipotesis statistik sebagai berikut:

Ha : pyx1>o

Ho : $\operatorname{pyx} 1=0$

Secara individual uji statistik yang digunakan adalah uji t yang dihitung Analisis juga bisa dilakukan dengan formula sebagai berikut: (Harun Al Rasyid, 2005)

$R_{x_{u}\left(x_{1}, x_{2}, \ldots x_{k}\right)}^{2}=\left(\begin{array}{llll}\rho_{x_{u} x_{1}} & \rho_{x_{u} x_{2}} & \ldots & \rho_{x_{u} x_{k}}\end{array}\right)\left[\begin{array}{c}r_{x_{u} x_{1}} \\ r_{x_{u} x_{2}} \\ \ldots \\ r_{x_{u} x_{k}}\end{array}\right]$

Dimana :

- $\mathrm{R}^{2^{x_{u}\left(x_{1}, x_{2} \ldots x_{k}\right)}}$ adalah koefisien determinasi total $\mathrm{X}_{1}, \mathrm{X}_{2}, \ldots \mathrm{X}_{\mathrm{k}}$ terhadap $\mathrm{X}_{\mathrm{u}}$ atau besarnya pengaruh variabel eksogenus secara bersama-sama (gabungan) terhadap variabel endogenus.

- $\left(\begin{array}{llll}\rho_{x_{u} x_{1}} & \rho_{x_{u} x_{2}} & \cdots & \rho_{x_{u} x_{k}}\end{array}\right)$ adalah koefisien jalur

- $\left(\begin{array}{llll}r_{x_{u} x_{1}} & r_{x_{u} x_{2}} & \ldots & r_{x_{u} x_{k}}\end{array}\right)$ adalah koefisien korelasi variabel eksogenus $\mathrm{X}_{1}, \mathrm{X}_{2}$, $\ldots \mathrm{X}_{\mathrm{k}}$ dengan variabel endogenus $\mathrm{X}_{\mathrm{u}}$. 
Dari rumus formula di atas dapat diketahui pengaruh bersama-sama (simultan) variabel eksogenus terhadap variabel endogenus. Untuk menghitung besarnya pengaruh langsung, pengaruh tidak langsung serta pengaruh total variabel eksogenus terhadap variabel endogenus secara parsial, dapat dilakukan dengan rumus : (Harun Al Rasyid, 2005)

1. Besarnya pengaruh langsung variabel eksogenus terhadap variabel endogenus $=\mathrm{p}^{x_{u} x_{i}} \times \mathrm{p}^{x_{u} x_{i}}$

2. Besarnya pengaruh tidak langsung variabel eksogenus terhadap variabel endogenus $=\mathrm{p}^{x_{u} x_{i}} \times \mathbf{r}^{x_{15}} \times \mathrm{p}^{x_{u} x_{i}}$

3. Besarnya pengaruh total variabel eksogenus terhadap variabel endogenus adalah penjumlahan besarnya pengaruh langsung dengan besarnya pangaruh

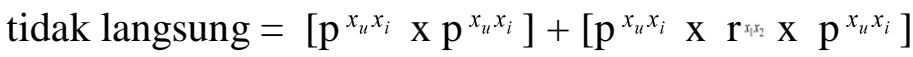

4. Diagram Jalur

Saat akan melakukan analisis jalur, disarankan terlebih dahulu menggambarkan secara diagramatik struktur hubungan kausal antara variabel penyebab dengan akibat.

Diagram ini disebut Diagram Jalur (Path Diagram). Bentuknya ditentukan proposisi teoritik berasal dari kerangka pikir tertentu.

\section{a. Koefisien Jalur (Path Coefficient)}

Besarnya pengaruh langsung dari suatu variabel eksogenus terhadap variabel endogenus tertentu, dinyatakan oleh besarnya nilai numerik koefisien jalur (path coefficient) dari eksogenus ke endogenus. (Harun Al Rasyid, 2005).

Hubungan antara $\mathrm{X}_{1}, \mathrm{X}_{2}, \mathrm{X}_{3}, \mathrm{X}_{4}$, dan $\mathrm{X}_{5}$ adalah hubungan korelasional. Intensitas keeratan hubungan tersebut dinyatakan oleh besarnya koefisien korelasi $\mathrm{r}^{\pi_{15}}$. Hubungan $\mathrm{X}_{1}, \mathrm{X}_{2}$ dan $\mathrm{X}_{3}, \mathrm{X}_{4}, \mathrm{X}_{5}$ ke $\mathrm{Y}_{1}$ adalah hubungan kausal. Besarnya pengaruh langsung dari $\mathrm{X}_{1}$ ke $\mathrm{Y}, \mathrm{X}_{2}$ ke $\mathrm{Y}$ dan dari $\mathrm{X}_{3}$ ke $\mathrm{Y}_{1}$, masing-masing dinyatakan oleh besarnya nilai numerik koefisien jalur $\mathrm{P}^{x_{1}}, \mathrm{P}^{x_{2}}$, dan $\mathrm{P}^{x_{3}}$ Koefisien jalur $\mathrm{P}^{x_{\varepsilon}}$ menggambarkan besarnya pengaruh langsung variabel residu 
(implicit exogenous variable) terhadap Y.

\section{b. Pengujian Koefisien Jalur Secara Induvidu}

Menguji kebermaknaan (test of significance) p koefisien jalur yang telah dihitung, baik secara sendiri-sendiri maupun secara bersama-sama, serta menguji perbedaan besarnya pengaruh masing-masing variabel eksogenus terhadap variabel endogenus, dapat dilakukan dengan langkah kerja berikut :(Harun Al Rasyid, 2005).

c. Menyatakan hipotesis statistik (hipotesis operasional) yang akan diuji.

$\mathrm{H}_{\mathrm{o}}: \mathrm{p}^{x_{u} x_{i}}=0$, artinya tidak terdapat pengaruh variabel eksogenus $\left(\mathrm{X}_{\mathrm{u}}\right)$ terhadap variabel endogenus $\left(\mathrm{X}_{\mathrm{i}}\right)$.

$\mathrm{H}_{1}: \mathrm{p}^{x_{u} x_{i}} \neq 0$, artinya terdapat pengaruh variabel eksogenus $\left(\mathrm{X}_{\mathrm{u}}\right)$ terhadap variabel endogenus $\left(\mathrm{X}_{\mathrm{i}}\right)$.

Dimana $\mathrm{u}$ dan $\mathrm{i}=1,2, \ldots, \mathrm{k}$

d. Gunakan statistik uji yang tepat, yaitu :

e. Untuk menguji p koefisien jalur :

$$
t=\frac{p_{x_{u} x_{i}}}{\sqrt{\frac{\left(1-R^{2}{ }_{x_{u}\left(x_{1} x_{2} \ldots x_{k}\right)}\right) C_{i i}}{n-k-1}}}
$$

dimana:

$\mathrm{i}=1,2, \ldots \mathrm{k}$

$\mathrm{k}$ = Banyaknya variabel eksogenous dalam substruktur yang sedang diuji

$\mathrm{t}=$ Mengikuti tabel distribusi $\mathrm{t}$, dengan derajat bebas $=\mathrm{n}-\mathrm{k}-$

\section{Hasil Dan Pembahasan}

\section{Analisis Uji Validasi}

Berdasarkan uji validasi diketahui hasil perbandingan antara $r_{\text {hitung }}$ yang merupakan koefisien korelasi dengan $r_{\text {ketetapan }}$ yang menunjukkan bahwa semua $\mathrm{r}_{\text {hitung }}$ lebih besar. Dengan demikian dapat diambil kesimpulan bahwa semua item pernyataan dalam kuisioner adalah valid. Yang artinya variabel tersebut mampu mengukur aspek yang sama atau apa yang ingin diukur oleh peneliti. 


\section{Analisis Uji Reliablity}

Dalam menguji reliabilitas dilakukan dengan cara mencari angka reliabilitas butir-butir pernyataan dari kuisioner dengan rumus standar item alpha. Setelah diperoleh nilai alpha, selanjutnya membandingkan nilai tersebut dengan angka kritis yang telah ditentukan. Pada pengujian ini uji reliabiilitas menggunakan software SPSS for Windows 22.0 dengan pendekatan Statistics Cronbach Alpha. Karena jumlah butir pernyataan untuk masing-masing variabel kurang dari sepuluh item, maka suatu variabel dikatakan relaibel jika nilai Cronbach Alpha> 0,60 (Santoso, 2001).

Berdasarkan uji reliability diketahui nilai $\alpha \mathrm{p}$ variabel $>$ dari nilai kritis reliabilitas. Variabel Tangibility $\left(\mathrm{X}_{1.1}\right)$ 0,852>0,60, variabel Reliability $\left(\mathrm{X}_{1 \cdot 2}\right)$ 0,746 $>0,60$, Responsiveness $\left(\mathrm{X}_{1.3}\right)$ 0,844>0,60, Assurance $\left(\mathrm{X}_{1.4}\right)$ 0,787>0,60, Empathy $\left(\mathrm{X}_{1} .5\right)$ 0,800> 0,60, variabel Customer Satisfaction $\left(\mathrm{Y}_{1}\right)$ 0,718> 0,60, dan Customer Loyality $\left(\mathrm{Y}_{2}\right)$ 0,737>0,60. Berdasarkan hasil perhitungan di atas maka bisa ditarik kesimpulan bahwa semua item pernyataan dalam kuisioner dapat dipercaya sebab hasil pengukuran relatif konsisten. Meskipun pernyataan tersebut diberikan dua kali atau lebih pada responden yang berbeda sehingga kuisioner ini dapat digunakan untuk penelitian selanjutnya.

\section{Uji Asumsi Klasik}

\subsection{Uji Normalitas}

Uji normalitas adalah uji untuk mengetahui normalitas dan bertujuan untuk menguji apakah variabel terikat dan variabel bebas keduanya mempunyai distribusi normal atau tidak. Pengujian normalitas dapat diketahui pada bahwa jalur pertama dan kedua data menyebar di sekitar garis diagonal damana mengikuti arah garis diagonal, sehingga pada model regresi tersebut memenuhi asumsi normalitas.

\subsection{Uji Multikolinearitas}

Uji multikolinearitas bertujuan untuk mengetahui ada tidaknya hubungan linear yang sempurna diantara variabel-variabel bebas dalam regresi. Untuk mengetahui ada tidaknya gejala multikolinearitas dapat dilihat dari besarnya nilai tolerance dan VIF (Varians Inflation Factor) melalui program SPSS. Berdasarkan uji Multikolinearitas diketahui nilai tolerance variabel Tangibility 0,955 , nilai VIF 
1,047. Nilai tolerance variabel Reliability 0,810 , nilai VIF 1,235. Nilai tolerance variabel Responsiveness 0,797 nilai VIF 1,255. Nilai tolerance variabel Assurance 0,825, nilai VIF 1,213. Nilai tolerance variabel Emphaty 0,828, nilai VIF 1,207. Dari uji di atas diketahui model regresi untuk jalur pertama dan kedua mempunyai nilai VIF di sekitar angka 1 dan nilai tolerance mendekati angka 1. Maka dapat dapat disimpulkan bahwa model regresi untuk jalur pertama dan jalur dua tidak terjadi gejala multikolinieritas.

\subsection{Uji Heteroskedastisitas}

Heteroskedastisitas muncul ketika varian dari distribusi probabilitas gangguan tidak konstan untuk seluruh pengamatan atas variabel penelitian. Metode yang digunakan untuk menguji heteroskedastisitas dalam penelitian ini memakai diagram scatterplot. Berdasarkan hasil uji Heteroskedastisitas dapat disimpulkan bahwa tidak ada pola yang jelas dalam pengujian terhadap variabel customer loyality serta titik-titik menyebar ke atas dan di bawah 0 pada sumbu Y maka tidak terjadi heteroskedastisitas.

\section{Analisis Jalur}

Proses perhitungan koefisien jalur dalam penelitian ini menggunakan software SPSS Versi 22.0. Nilai koefisien jalur ditunjukan oleh nilai output SPSS yang dinamakan Coefficient dan dinyatakan sebagai Standardized Coeffitient atau dikenal dengan nilai Beta. Koefisien jalur dalam model struktural perlu diuji signifikansinya sehingga dapat diperoleh koefisien jalur yang tidak signifikan dan koefisien jalur yang signifikan.

Koefisien jalur yang tidak signifikan dapat dihilangkan/dihapus dengan menerapkan model trimming. Hasil dari pengujian koefisien jalur tersebut digunakan untuk menjawab hipotesis penelitian yang dirumuskan. Hasil pengujian koefisien jalur (path coefficient) pengaruh langsung disajikan pada Tabel 1. 
Tabel 1. Koefisien Pengaruh Langsung

\begin{tabular}{|l|l|r|r|l|}
\hline $\begin{array}{l}\text { Variabel } \\
\text { Independent }\end{array}$ & Variabel Dependent & $\begin{array}{l}\text { Koefisien } \\
\text { Standardiz } \\
\boldsymbol{e}\end{array}$ & p-value & Keterangan \\
\hline Tangibility & Customer Satisfaction & 0,070 & 0,438 & Tidak Signifikan \\
\hline Reliability & Customer Satisfaction & 0,205 & 0,038 & Signifikan \\
\hline $\begin{array}{l}\text { Responsivenes } \\
\text { s }\end{array}$ & Customer Satisfaction & $-0,054$ & 0,584 & Tidak Signifikan \\
\hline Assurance & Customer Satisfaction & $-0,023$ & 0,816 & Tidak Signifikan \\
\hline Empathy & Customer Satisfaction & 0,182 & 0,061 & Tidak Signifikan \\
\hline Tangibility & Customer Loyalty & 0,047 & 0,528 & Tidak Signifikan \\
\hline Reliability & Customer Loyalty & 0,165 & 0,046 & Signifikan \\
\hline Responsiveness & Customer Loyalty & 0,086 & 0,049 & Signifikan \\
\hline Assurance & Customer Loyalty & 0,217 & 0,007 & Signifikan \\
\hline Empathy & Customer Loyalty & 0,293 & 0,000 & Signifikan \\
\hline $\begin{array}{l}\text { Customer } \\
\text { Satisfaction }\end{array}$ & Customer Loyalty & 0,193 & 0,012 & Signifikan \\
\hline & & & & \\
\hline
\end{tabular}

Tabel di atas menunjukkan paling dominan berpengaruh terhadap Customer Satisfaction adalah variabel Reliability dengan koefisien jalur langsung sebesar 0,205. Sedangkan jalur 2 variabel Empathy berpengaruh paling dominan terhadap Customer Loyalty dengan koefisien jalur pengaruh langsung sebesar 0,293.

Hal ini menunjukkan bahwa jalur dari Reliability menuju Customer Satisfaction, dan jalur dari Empathy menuju Customer Loyalty merupakan jalur yang paling kuat. Dari tabel di atas menunjukkan bahwa lima variabel independen yakni Tangibility, Reliability, Responsiveness, Assurance dan Empathy lebih kecil berpengaruh secara langsung terhadap Customer Satisfaction dibandingkan pengaruh langsungnya terhadap Customer Loyalty.

Artinya para pelanggan Koran Jawa Pos Radar Jember lebih berorientasi pada Customer Loyalty dari pada Customer Satisfaction. Pelanggan Koran Jawa Pos Radar Jember tidak benar-benar puas dulu untuk mendapatkan kesetiaan pelanggan. Hal ini bisa dilihat nilai pengaruh secara langsung Customer Satisfaction terhadap Customer Loyalty yang hanya memiliki pengaruh sebesar 0,193 atau $19,1 \%$. 


\begin{tabular}{|c|c|c|c|c|c|c|c|}
\hline \multicolumn{8}{|c|}{ Tabel 2 Coefficients ${ }^{\text {a }}$ Customer Satisfaction } \\
\hline \multirow[b]{2}{*}{ Model } & \multicolumn{2}{|c|}{$\begin{array}{l}\text { Unstandardized } \\
\text { Coefficients }\end{array}$} & \multirow{2}{*}{$\begin{array}{l}\text { Standardize } \\
\mathrm{d} \\
\text { Coefficient } \\
\mathrm{s}\end{array}$} & \multirow[b]{2}{*}{$\mathrm{t}$} & \multirow[b]{2}{*}{ Sig. } & \multicolumn{2}{|c|}{$\begin{array}{l}\text { Collinearity } \\
\text { Statistics }\end{array}$} \\
\hline & B & $\begin{array}{l}\text { Std. } \\
\text { Error }\end{array}$ & & & & Tolerance & VIF \\
\hline 1 (Constant) & 23.929 & 3.214 & & 7.446 & .000 & & \\
\hline Tangibility & .209 & .268 & .070 & .778 & .438 & .955 & 1.047 \\
\hline Reliability & .400 & .190 & .205 & 2.102 & .038 & .810 & 1.235 \\
\hline Responsiveness & -.128 & .233 & -.054 & -.549 & .584 & .797 & 1.255 \\
\hline Assurance & -.057 & .245 & -.023 & -.233 & .816 & .825 & 1.213 \\
\hline Empathy & .265 & .140 & .182 & 1.892 & .061 & .828 & 1.207 \\
\hline
\end{tabular}

\section{Pengujian Hipotesis 1 Tangibility $\left(\mathrm{X}_{1}\right)$ Terhadap Customer Satisfaction $\left(\mathrm{Y}_{1}\right)$}

Hipotesis pertama menyatakan terdapat pengaruh signifikan Tangibility terhadap Customer Satisfaction pelanggan Jawa Pos Radar Jember. Berdasarkan hasil pengujian koefisien jalur pada tabel 2 di bawah menunjukkan nilai t-hitung sebesar 0,778 sedangkan pada t- tabel sebesar 1,98 (df 118 dengan tingkat kepercayaan 5\%). Nilai ini menunjukkan bahwa nilai t-hitung lebih besar daripada t-tabel. Sedangakan nilai signifikansinya adalah sebesar 0,438 lebih besar dari 0,05. Dengan demikian maka hipotesis pertama ditolak. Artinya variabel Tangibility tidak berpengaruh signifikan terhadap Customer Satisfaction pelanggan Jawa Pos Radar Jember. Standardized coeficient atau nilai beta menunjukkan angka sebesar 0,209. Artinya besarnya pengaruh Tangibility terhadap Customer Satisfaction adalah sebesar $20,9 \%$.

\section{Pengujian Hipotesis 2 Reliability $\left(\mathrm{X}_{2}\right)$ Terhadap Cutomer Satisfaction ( $\left.\mathrm{Y}_{1}\right)$}

Hipotesis kedua menyatakan terdapat pengaruh signifikan Reliability terhadap Customer Satisfaction pelanggan Jawa Pos Radar Jember. Berdasarkan hasil pengujian koefisien jalur pada tabel 2 di atas menunjukkan nilai t-hitung sebesar 2,102 sedangkan pada t- tabel sebesar 1,98 (df 118 dengan tingkat kepercayaan 5\%). Nilai ini menunjukkan bahwa nilai t-hitung lebih besar dari pada t-tabel. Selain itu, pada pengujian koefisien jalur juga menunjukkan nilai signifikansi sebesar 0,038 lebih kecil dari 0,05. Dengan demikian maka hipotesis kedua terbukti atau diterima. Artinya variabel Reliability berpengaruh signifikan 
terhadap Customer Satisfaction pelanggan Jawa Pos Radar Jember. Standardized Coeficient atau nilai beta menunjukkan angka sebesar 0,205, artinya besarnya pengaruh Reliability terhadap Customer Satisfaction sebesar 20,5\%.

\section{Pengujian Hipotesis ke-3 $\mathrm{X}_{3}$ Terhadap Customer Satisfaction ( $\mathrm{Y}_{1}$ )}

Hipotesis ketiga menyatakan terdapat pengaruh signifikan Responsiveness terhadap Customer Satisfaction pelanggan Jawa Pos Radar Jember. Berdasarkan hasil pengujian koefisien jalur pada tabel 2 di atas menunjukkan nilai t-hitung sebesar -0.549. Sedangkan t- tabel sebesar 1,98 (df 118 dengan tingkat kepercayaan $5 \%$ ). Nilai ini menunjukkan bahwa nilai t-hitung lebih kecil dari pada t-tabel. Selain itu, pada pengujian koefisien jalur menunjukkan nilai signifikansi sebesar 0,584 lebih besar dari 0,05. Dengan demikian maka hipotesis ketiga yang menyatakan bahwa variabel Responsiveness tidak berpengaruh secara signifikan terhadap Customer Satisfaction pelanggan Jawa Pos Radar Jember tidak terbukti atau hipotesis ketiga ditolak. Artinya variabel Responsiveness tidak berpengaruh secara signifikan terhadap Customer Satisfaction pelanggan Jawa Pos Radar Jember.

\section{Pengujian Hipotesis Assurance (X4) Terhadap Customer Satisfaction ( $\mathrm{Y}_{1}$ )}

Hipotesis keempat menyatakan terdapat pengaruh signifikan Assurance terhadap Customer Satisfaction pelanggan Jawa Pos Radar Jember. Berdasarkan hasil pengujian koefisien jalur pada tabel 2 menunjukkannilai t-hitung sebesar 0,233. Sedangkan t- tabel sebesar 1,98 (df 118 dengan tingkat kepercayaan 5\%). Nilai ini menunjukkan bahwa nilai t-hitung lebih kecil dari pada t-tabel. Selain itu, pada pengujian koefisien jalur menunjukkan nilai signifikansi sebesar 0, 816 lebih besar dari 0,05. Dengan demikian maka hipotesis keempat yang menyatakan bahwa variabel Assurance berpengaruh secara signifikan terhadap Customer Satisfaction pelanggan Jawa Pos Radar Jember tidak terbukti atau hipotesis ketiga ditolak. Artinya variabel Assuranace tidak berpengaruh secara signifikan terhadap Customer Satisfaction pelanggan Jawa Pos Radar Jember.

\section{Pengujian Hipotesis ke-5 (Empathy )X $\mathrm{X}_{5}$ Terhadap (Customer Satisfaction) $\mathrm{Y}_{1}$}

Hipotesis kelima menyatakan terdapat pengaruh signifikan Empathy terhadap Customer Satisfaction pelanggan Jawa Pos Radar Jember. Berdasarkan hasil pengujian koefisien jalur pada tabel 2 menunjukkannilai t-hitung sebesar 
1,892. Sedangkan t- tabel sebesar 1,98 (df 118 dengan tingkat kepercayaan $5 \%)$.Nilai ini menunjukkan bahwa nilai t-hitung lebih besar dari pada t-tabel. Selain itu, pada pengujian koefisien jalur menunjukkan nilai signifikansi sebesar 0,061 lebih besar dari 0,05. Dengan demikian maka hipotesis kelima yang menyatakan bahwa variabel Empathy berpengaruh secara signifikan terhadap Customer Satisfaction pelanggan Jawa Pos Radar Jember tidak terbukti atau hipotesis ketiga ditolak. Artinya variabel Empathy tidak berpengaruh secara signifikan terhadap Customer Satisfaction pelanggan Jawa Pos Radar Jember.

1. Pengujian ke -6

Hipotesis keenam menyatakan terdapat pengaruh signifikan Tangibility terhadap Customer Loyalty pelanggan Jawa Pos Radar Jember. Berdasarkan hasil pengujian koefisien jalur pada tabel 3 menunjukkan nilai t-hitung sebesar 0,632 sedangkan pada t- tabel sebesar 1,98 (df 118 dengan tingkat kepercayaan 5\%). Nilai ini menunjukkan bahwa nilai t-hitung lebih kecil daripada t-tabel. Hasil analisis jalur menunjukkan nilai signifikansi sebesar 0,528 lebih besar dari 0,05, dengan demikian maka hipotesis keenam yang menyatakan bahwa variabel Tangibility berpengaruh signifikan terhadap Customer Loyalty tidak terbukti atau hipotesis keempat ditolak. Artinya Tangibility tidak berpengaruh secara signifikan terhadap Customer Loyalty pelanggan Jawa Pos Radar Jember. Dengan kata lain peningkatan terhadap Tangibility tidak lantas dapat meningkatkan Customer Loyalty pelanggan Jawa Pos Radar Jember.

\section{Pengujian Hipotesis ke- 7 Reliability $\left(\mathrm{X}_{2}\right)$ Terhadap Customer Loyalty $\left(\mathrm{Y}_{2}\right)$}

Hipotesis ketujuh menyatakan Reliability berpengaruh signifikan terhadap Customer Loyalty pelanggan Jawa Pos Radar Jember. Berdasarkan hasil pengujian koefisien jalur pada tabel 3 menunjukkan nilai t-hitung sebesar 0,049 sedangkan pada t- tabel t- tabel sebesar 1,98 (df 118 dengan tingkat kepercayaan 5\%). Nilai ini menunjukkan bahwa nilai t-hitung lebih besar dari pada t-tabel. Selain itu, pada pengujian koefisien jalur juga menunjukkan nilai signifikansi sebesar 0,049 lebih kecil dari 0,05. Dengan demikian maka hipotesis ketujuh terbukti atau diterima. Artinya variabel Reliability berpengaruh signifikan terhadap Customer Loyalty pelanggan Jawa Pos Radar Jember. Dari hasil analisis jalur diperoleh Standardized 
Coeficient atau nilai beta sebesar 0,165 artinya besarnya pengaruh Reliability pelanggan Jawa Pos Radar Jember adalah sebesar 16,5\%.

\section{Pengujian Hipotesis 8 Responsiveness $\left(\mathrm{X}_{3}\right)$ Terhadap Customer Loyalty $\left(\mathrm{Y}_{2}\right)$}

Hipotesis ke delapan menyatakan Responsiveness berpengaruh signifikan terhadap Customer Loyalty pelanggan Jawa Pos Radar Jember. Berdasarkan hasil pengujian koefisien jalur pada tabel 3 menunjukkan nilai t-hitung untuk variabel Responsiveness adalah sebesar 0,049 sedangkan pada t- tabel sebesar 1,98 (df 118 dengan tingkat kepercayaan 5\%). Nilai ini menunjukkan bahwa nilai t-hitung lebih kecil daripada t-tabel. Hasil analisis jalur menunjukkan nilai signifikansi sebesar 0,049 lebih kecil dari 0,05, dengan demikian maka hipotesis kedelapan yang menyatakan bahwa variabel Responsiveness berpengaruh signifikan terhadap Customer Loyalty pelanggan Jawa Pos Radar Jember atau hipotesis kedelapan diterima. Artinya Responsiveness berpengaruh secara signifikan terhadap Customer Loyalty pelanggan Jawa Pos Radar Jember. Dengan kata lain peningkatan terhadap Responsiveness yang diberikan dapat meningkatkan Customer Loyalty pelanggan Jawa Pos Radar Jember.

Tabel 3 Coefficients a Customer Loyalty

\begin{tabular}{|c|c|c|c|c|c|c|c|}
\hline \multirow[b]{2}{*}{ Model } & \multicolumn{2}{|c|}{$\begin{array}{l}\text { Unstandardized } \\
\text { Coefficients }\end{array}$} & \multirow{2}{*}{$\begin{array}{l}\text { Standardized } \\
\text { Coefficients } \\
\text { Beta } \\
\end{array}$} & \multirow[b]{2}{*}{$t$} & \multirow[b]{2}{*}{ Sig. } & \multicolumn{2}{|l|}{$\begin{array}{l}\text { Collinearity } \\
\text { Statistics } \\
\end{array}$} \\
\hline & $B$ & Std. Error & & & & Tolerance & VIF \\
\hline $1 \quad$ (Constant) & 4.881 & 3.192 & & 1.529 & .129 & & \\
\hline Tangibility & .140 & .221 & .047 & .632 & .528 & .951 & 1.052 \\
\hline Reliability & .321 & .159 & .165 & 2.018 & .046 & .781 & 1.281 \\
\hline Responsiveness & .203 & .192 & .086 & 1.061 & .049 & .795 & 1.258 \\
\hline Assurance & .546 & .201 & .217 & 2.721 & .007 & .824 & 1.213 \\
\hline Empathy & .423 & .116 & .293 & 3.633 & .000 & .804 & 1.243 \\
\hline $\begin{array}{l}\text { Customer } \\
\text { Satisfaction }\end{array}$ & .193 & .075 & .194 & 2.567 & .012 & .915 & 1.092 \\
\hline
\end{tabular}

a. Dependent Variabel: Customer Loyalty

\section{Pengujian Hipotesis ke-9 Assurance (X4) Terhadap Customer Loyalty ( $\left.\mathbf{Y}_{2}\right)$}

Hipotesis kesembilan menyatakan variabel Assurance berpengaruh signifikan terhadap Customer Loyalty pelanggan Jawa Pos Radar Jember. Berdasarkan hasil pengujian koefisien jalur pada tabel 3 menunjukkan nilai t-hitung untuk variabel Customer Loyalty adalah sebesar 0,007 sedangkan pada t- tabel t- 
tabel sebesar 1,98 (df 118 dengan tingkat kepercayaan 5\%). Nilai ini menunjukkan bahwa nilai t-hitung lebih kecil daripada t-tabel. Hasil analisis jalur menunjukkan nilai signifikansi sebesar 0,007 lebih kecil dari 0,05. Dengan demikian maka hipotesis kesembilan yang menyatakan bahwa variabel Assurance berpengaruh positif dan signifikan terhadap Customer Loyalty pelanggan Jawa Pos Radar Jember terbukti atau hipotesis kesembilan diterima. Artinya Assurance berpengaruh secara signifikan terhadap Customer Loyalty pelanggan Jawa Pos Radar Jember. Dengan kata lain peningkatan terhadap Assurance dapat meningkatkan Customer Loyalty pelanggan Jawa Pos Radar Jember.

\section{Pengujian Hipotesis ke-10 Empathy (X5) Terhadap Customer Loyalty ( $\left.\mathrm{Y}_{2}\right)$}

Hipotesis kesepuluh menyatakan variabel Empathy berpengaruh signifikan terhadap Customer Loyalty pelanggan Jawa Pos Radar Jember. Berdasarkan hasil pengujian koefisien jalur pada tabel 3 menunjukkan nilai t-hitung untuk variabel Empathy adalah sebesar 0,000 sedangkan pada t- tabel t- tabel sebesar 1,98 (df 118 dengan tingkat kepercayaan 5\%). Nilai ini menunjukkan bahwa nilai t-hitung lebih kecil daripada t-tabel. Hasil analisis jalur menunjukkan nilai signifikansi sebesar 0,000 lebih kecil dari 0,05. Dengan demikian maka hipotesis kesembilan yang menyatakan bahwa variabel Empathy berpengaruh positif dan signifikan terhadap Customer Loyalty pelanggan Jawa Pos Radar Jember terbukti atau hipotesis kesepuluh diterima. Artinya Empathy berpengaruh secara signifikan terhadap Customer Loyalty pelanggan Jawa Pos Radar Jember. Dengan kata lain peningkatan terhadap Empathy dapat meningkatkan Customer Loyalty pelanggan Jawa Pos Radar Jember.

\section{Pengujian Hipotesis 11 Customer Satisfaction ( $\left.\mathbf{Y}_{1}\right)$ Terhadap Customer Loyalty $\left(\mathbf{Y}_{2}\right)$}

Hipotesis kesebelas menyatakan variabel Customer Satisfaction memediasi signifikan Service Quality terhadap Customer Loyalty pelanggan Jawa Pos Radar Jember. Berdasarkan Uji Sobel dengan aplikasi Sobel Test Calculator for the Significance of Mediation diperoleh hasil sebagai berikut :

$\mathrm{X} 1$ ke Y2 melalui Y1 = 1,0363

$\mathrm{X} 2$ ke $\mathrm{Y} 2$ melalui $\mathrm{Y} 1=1,6041$ 
$\mathrm{X} 3$ ke Y2 melalui $\mathrm{Y} 1=-0,5732$

$\mathrm{X} 4$ ke Y2 melalui $\mathrm{Y} 1=-0,2317$

X5 ke Y2 melalui Y1 = 1,1061

Berdasarkan uji sobel diketahui bahwa thitung variabel Tangibility terhadap Customer Loyalty melalui Customer Satisfaction sebesar 1,0363. Hasil t hitung variabel Reliability terhadap Customer Loyalty melalui Customer Satisfaction 1,6041. Hasil t hitung variabel Responsiveness terhadap Customer Loyalty melalui Customer Satisfaction -0,5732. Hasil t hitung variabel Assurance terhadap Customer Loyalty melalui Customer Satisfaction -0,2317. Hasil t hitung variabel Emptahy terhadap Customer Loyalty melalui Customer Satisfaction 1,1061. Dengan demikian disimpulkan bahwa $\mathrm{T}$ hitung Tangibility, Reliability, Responsiveness, Assurance dan Emphaty semuanya dibawah nilai t tabel sebesar 1,98. Dengan demikian Customer Satisfaction tidak memediasi Service Quality terhadap Customer Loyalty.

\section{Pembahasan}

Pada pembahasan ini akan diuraikan interpretasi dari hasil analisis data yang telah disajikan sebelumnya. Berdasarkan hasil penelitian 125 pelanggan Jawa Pos Radar Jember sebagian besar responden memberikan jawaban yang cukup baik. Diskripsi atas indikator variabel yang diteliti ini, memberikan informasi tentang tinggi atau rendahnya variabel tersebut dalam mempengaruhi Customer Satisfaction dan Customer Loyalty pelanggan Jawa Pos Radar Jember. Pembahasan pada $\mathrm{p}$ hipotesis yang diajukan dalam penelitian adalah sebagai berikut:

\section{Pengaruh Tangibility terhadap Customer Satisfaction pelanggan Jawa Pos Radar Jember}

Berdasarkan penilaian pelanggan Jawa Pos Radar Jember yang menjadi responden Menunjukkan Tangibility atau bukti fisik Koran Jawa Pos, khususnya kopel Radar Jember memiliki pengaruh yang lemah terhadap Customer Satisfaction. Hasil analisis jalur menyatakan bahwa Tangibility berpengaruh tidak signifikan pada Customer Satisfaction koran Jawa Pos Radar Jember. Hal ini menunjukkan bahwa semakin baik Tangibility Jawa Pos Radar Jember maka semakin tinggi Customer Satisfaction yang dirasakan pelanggannya. Demikian juga 
sebaliknya semakin Tangibility Jawa Pos Radar Jember maka semakin rendah Customer Satisfaction pelanggannya. Penelitian ini konsisten dengan penelitian yang dilakukan Kartikasari (2008), Januar (2016), Febriani (2017), wan (2015). Juga sejalan dengan Widiyono, Hakim (2018), Utama, (2017). Penelitian-penelitian tersebut menyatakan bahwa ada hubungan antara Tangibility dalam Service Quality dengan Customer Satisfaction.

\section{Pengaruh Reliability terhadap Customer Satisfaction pelanggan Jawa Pos Radar Jember}

Berdasarkan penilaian pelanggan Jawa Pos Radar Jember yang menjadi responden menunjukkan Reliabilty atau keandalan Koran Jawa Pos dapat meningkatkan Customer Satisfaction pelanggan Jawa Pos Radar Jember. Hasil analisis Jalur menyatakan bahwa Reliabilty berpengaruh signifikan terhadap Customer Satisfaction. Artinya keandalan dibutuhkan untuk mencapai tingkat kepuasan pelanggan Jawa Pos Radar Jember. Hasil penelitian ini sejalan dengan dari Kartikasari (2008). Bahwa Reliability memengaruhi kepuasan pelanggan Jawa Pos Radar Jember. Penelitian Febriani (2017) yang menyatakan kualitas layanan mempunyai pengaruh yang positif dan signifikan terhadap kepuasan pelanggan. Kemudian sesuai dengan penelitian yang menyatakan bahwa kualitas produk, kualitas layanan dan kepuasan konsumen memiliki pengaruh terhadap loyalitas konsumen dan adanya pengaruh tidak langsung melalui kepuasan konsumen. Pada realita di lapangan keandalan Jawa Pos Radar Jember memang dirasa sudah baik. Untuk itu pihak Jawa Pos Radar Jember tetap perlu mempertahankan dan meningkatkan nilai-nilai yang dapat membangun keandalkan atau kepercayaan pelanggan Jawa Pos Radar Jember.

\section{Pengaruh Responsiveness terhadap Customer Satisfaction pelanggan Jawa}

\section{Pos Radar Jember}

Berdasarkan penilaian pelanggan Jawa Pos Radar Jember yang menjadi responden menunjukkan Responsiveness atau cepat tanggap Koran Jawa Pos tidak dapat meningkatkan Customer Satisfaction pelanggan Jawa Pos Radar Jember. Hasil penelitian menyatakan bahwa Responsiveness tidak berpengaruh signifikan Customer Satisfaction pelanggan Jawa Pos Radar Jember. Hal ini berarti semakin 
tinggi tingkat Responsiveness Jawa Pos Radar Jember maka Customer Satisfaction pelanggan Jawa Pos Radar Jember tidak makin besar. Hasil penelitian ini tidak sejalan dengan hasil penelitian Febriani (2017) yang menyatakan kualitas layanan mempunyai pengaruh yang positif dan signifikan terhadap kepuasan pelanggan dapat diterima.

\section{Pengaruh Assurance terhadap Customer Satisfaction pelanggan Jawa Pos Radar Jember}

Berdasarkan penilaian pelanggan Jawa Pos Radar Jember yang menjadi responden menunjukkan Assurance atau jaminan dari Koran Jawa Pos diketahui hasil penelitian menyatakan bahwa Assurance tidak berpengaruh signifikan Customer Satisfaction pelanggan Jawa Pos Radar Jember. Hal ini berarti semakin tinggi tingkat Assurance Jawa Pos Radar Jember maka Customer Satisfaction pelanggan Jawa Pos Radar Jember tidak makin besar. Hasil penelitian ini tidak konsisten dengan temuan Febriani (2017) dan yang menyatakan kualitas produk, kualitas layanan dan kepuasan konsumen memiliki pengaruh terhadap loyalitas konsumen dan adanya pengaruh tidak langsung melalui kepuasan konsumen.

\section{Pengaruh Empathy terhadap Customer Satisfaction pelanggan Jawa Pos}

\section{Radar Jember}

Berdasarkan penilaian pelanggan Jawa Pos Radar Jember yang menjadi responden menunjukkan Empathy Koran Jawa Pos tidak meningkatkan Customer Satisfaction pelanggan Jawa Pos Radar Jember. Hasil penelitian menyatakan bahwa Empathy tidak berpengaruh signifikan Customer Satisfaction pelanggan Jawa Pos Radar Jember. Hal ini berarti semakin tinggi tingkat Empathy Jawa Pos Radar Jember maka Customer Satisfaction pelanggan Jawa Pos Radar Jember tidak makin besar. Hasil penelitian ini tidak sejalan dengan temuan dalam penelitian yang dilakukan oleh Febriani (2017) yang menyatakan kualitas layanan mempunyai pengaruh yang positif dan signifikan terhadap kepuasan pelanggan dapat diterima. Kepuasan pelanggan berpengaruh terhadap loyalitas pelanggan.

\section{Pengaruh Tangibility terhadap Customer Loyalty pelanggan Jawa Pos Radar} Jember

Berdasarkan penilaian pelanggan Jawa Pos Radar Jember yang menjadi 
responden menunjukkan Tangibility atau bukti fisik Koran Jawa Pos tidak sepenuhnya dapat meningkatkan Customer Loyalty pelanggan Jawa Pos Radar Jember. Hasil penelitian menyatakan bahwa Tangibility tidak berpengaruh signifikan Customer Loyalty pelanggan Jawa Pos Radar Jember. Hal ini berarti semakin tinggi Tangibility Jawa Pos Radar Jember maka Customer Loyalty pelanggan Jawa Pos Radar Jember belum tentu makin besar. Hasil penelitian ini sejalan dengan hasil temuan penelitian Agustin (2018) menyatakan kualitas layanan secara parsial atau individu berpengaruh terhadap Loyalitas Pelanggan. Sejalan juga dengan Penelitian Kartikasari (2008) menyatakan terdapat pengaruh kualitas produk yang terdiri dari kinerja produk (Performance), keistimewaan produk (Features), keandalan produk (Reliability), kemampulayanan produk (Serviceability), serta persepsi kualitas produk (Perceived Quality) secara parsial terhadap loyalitas pelanggan koran Jawa Pos di Kecamatan Lowokwaru Kota Malang. Termasuk dengan penelitian Nababan (2017) yang menyatakan bahwa dimensi kualitas produk dan kualitas layanan berpengaruh terhadap loyalitas pembaca koran Pikiran Rakyat.

\section{Pengaruh Reliability terhadap Customer Loyalty pelanggan Jawa Pos Radar}

\section{Jember}

Berdasarkan penilaian pelanggan Jawa Pos Radar Jember yang menjadi responden menunjukkan Reliabilty atau keandalan Koran Jawa Pos dapat meningkatkan Customer Loyalty pelanggan Jawa Pos Radar Jember. Hasil penelitian menyatakan bahwa Reliability berpengaruh signifikan Customer Loyalty pelanggan Jawa Pos Radar Jember. Hal ini berarti semakin tinggi tingkat Reliability Jawa Pos Radar Jember maka Customer Loyalty pelanggan Jawa Pos Radar Jember makin besar. Penelitian ini sejalan dengan temuan penelitian Agustin (2018) menyatakan kualitas layanan secara parsial atau individu berpengharuh terhadap Loyalitas Pelanggan. Juga sejalan dengan penelitian Kartikasari (2008) menyatakan pengaruh kualitas produk yang terdiri dari kinerja produk (Performance), keistimewaan produk (Features), keandalan produk (Reliability), kemampulayanan produk (Serviceability), serta persepsi kualitas produk (Perceived Quality) secara parsial terhadap loyalitas pelanggan. 


\section{Pengaruh Responsiveness terhadap Customer Loyalty pelanggan Jawa Pos Radar Jember}

Berdasarkan penilaian pelanggan Jawa Pos Radar Jember yang menjadi responden menunjukkan Responsiveness atau cepat tanggap Koran Jawa Pos dapat meningkatkan Customer Loyalty pelanggan Jawa Pos Radar Jember. Hasil penelitian menyatakan bahwa Responsivnes berpengaruh signifikan Customer Loyalty pelanggan Jawa Pos Radar Jember. Hal ini berarti semakin tinggi tingkat Responsiveness Jawa Pos Radar Jember maka Customer Loyalty pelanggan Jawa Pos Radar Jember makin besar. Hasil penelitian ini sejalan dengan penelitian Nababan (2017), Agustin (2018) yang menyatakan dimensi harga, emosional, dan biaya serta kemudahan mendapatkan produk berpengaruh terhadap loyalitas. Juga menyatakan kualitas layanan secara parsial atau individu berpengharuh terhadap Loyalitas Pelanggan.

\section{Pengaruh Assurance terhadap Customer Loyalty pelanggan Jawa Pos Radar}

\section{Jember}

Berdasarkan penilaian pelanggan Jawa Pos Radar Jember yang menjadi responden menunjukkan Assurance atau jaminan Koran Jawa Pos dapat meningkatkan Customer Loyalty pelanggan Jawa Pos Radar Jember. Hasil penelitian menyatakan bahwa Assurance berpengaruh signifikan Customer Loyalty pelanggan Jawa Pos Radar Jember. Hal ini berarti semakin tinggi tingkat Assurance Jawa Pos Radar Jember maka Customer Loyalty pelanggan Jawa Pos Radar Jember makin besar. Hasil penelitian ini sejalan dengan penelitian Agustin (2018) yang menyatakan Assurance dalam Service Quality secara parsial atau individu berpengharuh terhadap Customer Loyalty. Bahwa jaminan kualitas koran Jawa Pos Radar Jember berpengharuh terhadap tingkat loyalitas pelanggan. Jaminan kualitas makin bagus maka tingkat loyalitas pelanggan koran Jawa Pos Radar Jember makin baik.

10. Pengaruh Empathy terhadap Customer Loyalty pelanggan Jawa Pos Radar Jember

Berdasarkan penilaian pelanggan Jawa Pos Radar Jember yang menjadi responden menunjukkan Empathy koran Jawa Pos dapat meningkatkan Customer 
Loyalty pelanggan Jawa Pos Radar Jember. Hasil penelitian menyatakan bahwa Empathy berpengaruh signifikan Customer Loyalty pelanggan Jawa Pos Radar Jember. Hal ini berarti semakin tinggi tingkat Empathy Jawa Pos Radar Jember maka Customer Loyalty pelanggan Jawa Pos Radar Jember makin besar. Penelitian ini konsisten dengan penelitian Agustin (2018), Nababan (2017), Agustin (2018) yang menyatakan kualitas layanan ada hubungan signifikan antara Empathy dengan Customer Loyalty pelanggan Jawa Pos Radar Jember. Bahwa factor psikologi/ empathy dalam service quality berpengaruh signifikan terhadap customer Loyalty

\section{Pengaruh Customer Satisfaction terhadap Customer Loyalty pelanggan Jawa Pos Radar Jember}

Berdasarkan penilaian pelanggan Jawa Pos Radar Jember yang menjadi responden menunjukkan Customer Satisfaction Koran Jawa Pos dapat meningkatkan Customer Loyalty pelanggan Jawa Pos Radar Jember. Hasil penelitian menyatakan bahwa Customer Satisfaction berpengaruh signifikan Customer Loyalty pelanggan Jawa Pos Radar Jember. Hal ini berarti semakin tinggi Customer Satisfaction Jawa Pos Radar Jember maka Customer Loyalty pelanggan Jawa Pos Radar Jember juga makin besar.

Itu sejalan dengan penelitian yang dilakukan Agustin (2018) yang menyatakan kualitas layanan (X2) secara parsial atau individu berpengharuh terhadap Loyalitas Pelanggan (Y). Kemudian juga sesuai dengan penelitian Nababan (2017). Yang menyatakan dimensi harga, emosional, dan biaya serta kemudahan mendapatkan produk berpengaruh terhadap loyalitas pembaca koran Pikiran Rakyat. Termasuk sejalan dengan penelitian Santoso (2015) menyatakan kepuasan pelanggan berpengaruh signifikan terhadap loyalitas pelanggan.

\section{Kimpulan}

Dari hasil pengujian dan analisis statistik dalam penelitian ini, maka dapat diambil beberapa kesimpulan antara lain sebagai berikut:

1. Variabel Tangibility tidak berpengaruh signifikan terhadap Customer Loyalty pelanggan koran Jawa Pos Radar Jember. Semakin bagus bentuk fisik koran Jawa Pos Radar Jember tidak meningkatkan loyalitas pelanggan. 
2. Variabel Reliabilty berpengaruh signifikan terhadap Customer Loyalty pelanggan koran Jawa Pos Radar Jember. Sehingga semakin tinggi keandalan koran Jawa Pos Radar Jember semakin meningkatkan loyalitas pelanggan.

3. Variabel Responsiveness berpengaruh signifikan terhadap Customer Loyalty pelanggan koran Jawa Pos Radar Jember. Semakin tinggi tanggapan koran Jawa Pos Radar Jember semakin meningkatkan loyalitas pelanggan.

4. Variabel Assurance berpengaruh signifikan terhadap Customer Loyalty pelanggan koran Jawa Pos Radar Jember. Semakin tinggi jaminan koran Jawa Pos Radar Jember sekaligus semakin meningkatkan loyalitas pelanggan.

5. Variabel Empathy berpengaruh signifikan terhadap Customer Loyalty pelanggan koran Jawa Pos Radar Jember. Semakin tinggi Empathy koran Jawa Pos Radar Jember semakin meningkatkan loyalitas pelanggan.

6. Variabel Tangibility dalam hal ini desain grafis dan judul tidak berpengaruh signifikan terhadap Customer Loyalty pelanggan koran Jawa Pos Radar Jember.

7. Variabel Reliability dalam hal ini isi berita sesuai kebutuhan pelangan, kecepatan koran sampai tujuan dan pelanggan mudah menemukan koran berpengaruh signifikan terhadap Customer Loyalty pelanggan koran Jawa Pos Radar Jember.

8. Variabel Responsiveness dalam hal ini keluhan yang langsung ditanggapi dan adanya kolom keluhan di Jawa Pos Radar Jember berpengaruh signifikan terhadap Customer Loyalty pelanggan koran Jawa Pos Radar Jember.

9. Variabel Assurance dalam hal ini kualitas berita yang terjaga dan berita Jawa Pos Radar Jember yang akurat berpengaruh signifikan terhadap Customer Loyalty pelanggan koran Jawa Pos Radar Jember.

10. Variabel Empathy dalam hal ini Jawa Pos Radar Jember memberikan reward, adanya gathering secara periodik dan penyaluran CSR yang 
dilakukan Jawa Pos Radar Jember berpengaruh signifikan terhadap Customer Loyalty pelanggan koran Jawa Pos Radar Jember.

11. Variabel Customer Satisfaction tidak memediasi Service Quality terhadap Customer Loyalty pelanggan koran Jawa Pos Radar Jember.

\section{Implikasi}

1. Pengujian koefisien determinasi $\left(\mathrm{R}^{2}\right)$ bertujuan untuk mengetahui seberapa besar kemampuan variabel independen dalam mempengaruhi variabel dependen. Dari hasil analisis diperoleh nilai koefisien determinasi sebesar 0,682. Besarnya pengaruh secara total terhadap variabel Customer Loyalty adalah sebesar $68,2 \%$, Sedangkan sisanya sebanyak 31,8 \% dipengaruhi oleh variabel lain yang tidak dimasukkan dalam penelitian ini. Seperti faktor pendidikan dan pelatihan, faktor individu, faktor lingkungan dan faktor stimuli pemasaran dan faktor lainnya.

2. Variabel Tangibility, Reliablity, Responsiveness, Assurance dan Empathy secara parsial tidak berpengaruh siginifkan terhadap Customer Satisfaction pelanggan Jawa Pos Radar Jember.

\section{Saran}

1. Dimensi Service Quality berupa Tangibility, Reliablity, Responsiveness, Assurance dan Empathy berpengaruh langsung terhadap Customer Loyality Pelanggan Koran Jawa Pos Radar Jember. Maka diharapkan Jawa Pos Radar Jember meningkatkan Service Quality melalui masing-mansing dimensinya sehingga pelanggan Koran Jawa Pos mendapatkan manfaat lebih baik sehingga lebih loyal.

2. Bagi peneliti yang akan datang disarankan tidak hanya melakukan penelitian terhadap Jawa Pos Radar Jember, khususnya kopel Radar Jember saja. Tetapi meneliti secara keselurahan koran Jawa Posnya, yang di dalamnya terdapat Radar Jember. Agar penelitiannya lebih sempurna.

3. Hasil penelitian ini selanjutnya diharapkan bisa menjadi referensi untuk penelitian selanjutnya. Sekaligus untuk menambah metode lain yang dapat meningkatkan kualitas penelitian. 
4. Berdasarkan hasil penelitian diketahui masih ada variabel lain yang berpengaruh terhadap loyalitas pelanggan. Peneliti lain bisa menyempurnakan penelitian ini dengan menggunakan variabel lain tersebut.

\section{DAFTAR PUSTAKA}

Agustin, 2018, Pengaruh Kualitas Pelayanan terhadap Loyalitas Pelanggan Koran Jawa Pos Radar Kediri. simki.unpkediri.ac.id. Simki-economic vol.02 no 03 Tahun 2018.

Al Rasyid, Harun Krismantoroadji, 2005, Statistika Sosial. Bandung. Program Pascasarjana Unpad Bandung.

Amin Widjaja Tunggal, 2008, Dasar-Dasar Customer Relationship Management (CRM), Harvindo, Jakarta.

Anggraini \& Ruzikna, 2015, Pengaruh Brand Image terhadap Loyalitas Pelanggan pada Koran Harian Riau Pos. JOM Fisip Vol. 3 No.1 Februari 2015.

Arikunto, Suharsimi, 2006, Prosedur Penelitian Suatu Pendekatan Praktik. Rineka Cipta. Jakarta.

Badan Pusat Statsitik,2018, Kabupaten Jember Dalam Angka 2018. Jember 2019. https://jemberkab.bps.go.id. Diakses pukul 08.00 Januari 2019.

Company profile Jawa Pos Radar Jember, 2015, Mengenal Jawa Pos Radar Jember. Jember

Febriani, 2017, Pengaruh Kualitas Pelayanan terhadap Kepuasan Pelanggan Koran Harian Fajar di Kota Makassar. repositori.uin-alauddin.ac.id. Date deposited. 19 Februari 2018. 02.03 WIB.

Ferdinand, Augusty, 2014, Metode Penelitian Manajemen, Badan Penerbit Universitas Diponegoro, Semarang.

Ghozali, Imam, 2016, Aplikasi Analisis Multivariete, dengan Program IBM SPSS 23. Badan Penerbit Universitas Diponegoro. Semarang.

Gujarati, Damodar, 2004, Ekonometrika Dasar. Penerbit Erlangga. Jakarta.

Gunawan, 2013, Pengaruh Brand Positioning terhadap Loyalitas Pelanggan Surat Kabar Pikiran Rakyat (Survey Terhadap Pembaca Surat Kabar Pikiran Rakyat di Kota Bandung). Edunomic Jurnal Pendidikan Ekonomi. Vol 1, No 2 Tahun 
2013.

Griffin, Jill, 2005, Customer Loyality : Menumbuhkan dan Mempertahankan Kesetiaan Pelanggan, Erlangga, Jakarta.

Hakim, Widiyono, 2018, Manajemen Strategis \& Isu-Isu Kekinian. Mitra Wacana Media, Jakarta

Hasan, Ali, 2013, Marketing, PT Buku Kita, Jakarta.

Januar, 2016, Pengaruh Citra Merek terhadap Loyalitas Konsumen di Koran Harian PT Riau Pos Intermedia Pekan Baru. https://www.neliti.com. JOM Fisip Vol. 3 No.2 Oktober 2016.

Kartikasari, 2008, Pengaruh Kualitas Produk Terhadap Loyalitas Pelanggan: Studi pada pelanggan koran Jawa Pos di wilayah Kecamatan Lowokwaru Kota Malang.

Kerlinger, Fred N, 1995, Asas-asas Penelitian Behavioral, Edisi Ketiga, Cetakan Keempat.

Kotler, Philip dan Keller, Kevin Lanne, 2009, Marketing Management. Essex. Penerbit Pearson Edication. Essex. England.

Kotler, Philip dan Gary Asmtrong, 2001, Prinsip-Prinsip Pemasaran, Jilid 2 Edisi kedelapan, Penerbit Erlangga, Jakarta.

Kotler dan Keller, 2017, Manajemen Pemasaran, Jilid 2 Edisi 12, penerbit PT Indeks Jakarta.

Margono, 2004, Metode Penelitian Pendidikan. Jakarta: Rineka Cipta.

Nababan, 2017, Analisis Faktor-Faktor yang Mempengaruhi Loyalitas Pembaca Koran Pikiran Rakyat Bandung. digilib.polban.ac.id.

Nilsen Indonesia, 2017, Masa Depan Media Cetak, dari Digitalisasi hingga Masalah Gaji. (marketeers.com). Diposting 15 Januari 2018.

Parasuraman A, Zeithaml, V. A, dan Leonard L. Berry, 1990, Delivering Quality Services, Free Press, New York.

Priyatno, 2012, Mandiri Belajar Analisis Data Dengan SPSS. Jakarta: Mediakom. 
Sari, Intan 2015, Pengaruh Kualitas Layanan Terhadap Kepuasan dan Loyalitas Konsumen di Rumah Sakit Umum Daerah Kabupaten Pasuruan. Tesis. STIE Mandala Jember.

Sembiring, I.J. dan Kusumawati, A, 2014, Pengaruh Kualitas Produk dan Kualitas Pelayanan Terhadap Kepuasan Pelanggan Dalam Membentuk Loyalitas Pelanggan. Jurnal Administrasi Bisnis, 15 (1) : 1-10.

Suwardjono, Aji, 2013, Seminar New Media: Pembaca, Laba dan Etika. (http://marketeers.com, 2013. Diakses 23 Maret 2013.

Schiffman, L.G dan L.L, Kanuk, 2000, Perilaku Konsumen, Edisi ke-7. Printice Hall New Jersey Christensen, Clayton, 2006, "The Future of Newspapers" Harvard Business School. USA.

Santoso, Japarianto, 2015, Pengaruh Relationship Marketing terhadap Kepuasan Pelanggan dan Loyalitas Pelanggan Koran Kompas di Surabaya. Jurnal Manajemen Pemasaran Petra Vol.1, No 1, Januari 2015.

Santoso, Singgih, 2001, SPSS Versi Mengolah Data Statistik Secara Profesional. PT. Elex Media Komputindo, Jakarta.

Sekaran, Uma, 2003, Research methods for business : a skill-building approach. 4th Edition, John Wiley \& Sons Inc, America.

Sugiyono, 2017, Metode Penelitian Kuantitatif dan $R \&$ D . PT Alfabeta, Bandung.

Swastha, Basu dan Irawan, 2008, Manajemen Pemasaran Modern, Liberty, Yogyakarta.

Tjiptono, Fandy dan Gregorius Chandra, 2011, Service Quality and Satisfaction (ed 3), Andi Yogyakarta.

Tjiptono, 2008, Strategi Pemasaran, Penerbit Andi Yogyakarta.

Utama, 2017, Pemasaran Pariwisata. Penerbit CV Andi Offset, Bali.

Wazis, Kun, 2013, Kuasa News Value, Kontruksi dan Aplikasi di Media Massa, Penerbit STAIN Jember Press.

Widagdo, Suwignyo, Armanu, Noermijati, and Rofiaty. 2014. "Effect of Political Marketing Mix on Constituents Behavior in Selecting Candidates and Political Parties: Theoretical Studies in Legislative Elections". International Journal of Business and Management Invention 3:47-54. 
Widarjono, Agus, 2010, Analisis Multivariat Terapan, dengan Program SPSS, AMOS, SMARTPLS, UPP STIM YKPN, Yogyakarta.

Widyasari, Soliha, Wuryan dan Damayanti, 2017, Pengaruh Kualitas Produk, Persepsi Harga dan Citra Merk Terhadap Kepuasan Serta Dampaknya Pada Loyalitas Pelanggan (Studi Empiris Pada Koran Harian Suara Merdeka di Kota Semarang). Jurnal Manajemen Bisnis Indonesia. Vol. 5 No.1 1 Oktober 2017.

Yunita, 2013, Pengaruh Kualitas Pelayanan, Kualitas Produk Berpengaruh Terhadap Loyalitas Pemasang Iklan atau Pelanggan di Radar Banten. https://anzdoc.com. 